\title{
Research on the Blended Learning Model of Universities under the Internet
}

\author{
Fei Feng, Peixue Liu, Yujie Chen, Baohua Jiang \\ Qingdao Huanghai College \\ Qingdao, 266427, Shandong, China \\ 1547752800@qq.com
}

\begin{abstract}
The rapid development of information technology provides the foundation for the mixed learning. Mixed learning includes various types of learning and the integration of various teaching modes. Teachers should make full use of network resources, the traditional mode of classroom teaching with online learning, give full play to the role of the teacher as the supervisor, arouse the enthusiasm of students' autonomous learning, and to improve the teaching quality.
\end{abstract}

\section{Keywords: Blended Learning; Internet; Teaching mode}

\section{INTRODUCTION}

With the continuous development of information technology, colleges and universities are gradually trying to introduce the network into the teaching process and develop a new teaching mode, namely discovery teaching, so that students can learn independently. In fact, the existing multimedia resources and network resources of some universities remain idle. Based on this kind of situation, in 2004, HE given the new connotation of "blended learning", namely in the undergraduate course colleges and universities, on the basis of traditional face-to-face teaching mode, combined with the current popular mode of online learning, on the one hand, give full play to the role of the teacher as the supervisor; On the other hand, with the help of new online learning methods, students can be effectively motivated to cultivate mutual awareness and enhance cooperation and cooperation.

\section{THE BASIC CONCEPT OF BLENDED LEARNING}

Blended learning is a new concept that has become prevalent in recent years. In particular, blended learning includes various types of learning and the integration of various teaching modes. Blended learning should be understood as in combination with the advantages of online learning and traditional learning style, and to respect the principal position of learners, teachers' leading role, at the right time, using some teaching function of network media technology, service to learners' needs, provide learning resources and activities that are carefully designed, finally obtain the best teaching effect.

\section{THE IMPORTANCE OF BLENDED LEARNING FOR UNDERGRADUATE TEACHING.}

In the actual teaching process of the undergraduate college, the application of hybrid learning is mainly to promote the transformation of learning mode effectively through blended learning, and thus effectively improve the teaching quality. Through the combination of traditional face-to-face teaching and online learning, we can improve network learning in the form of low input and high efficiency. Through blended teaching and discovery teaching, students can learn independently and consciously under the supervision and guidance of teachers, so as to promote the all-round development of students. In the actual teaching process, teachers can create a first class before the class situation. In this kind of situation, students can explore and think independently and get themselves in this kind of situation for the idea of a problem. At this time, the teacher can import to prepare questions in advance, by the students for a free exchange and discussion, group discussion, to students after the discussion by the teacher to ask questions and make discussion groups show results, final evaluation results of each group. In particular, the class teacher can put the video resources on the network platform, can let the students in their spare time to study the related resources doubts of students can make use of social media platforms to teachers' feedback in time. We can design a variety of interesting teaching activities, so that students can use the network resources to study, so as to change the students' learning style and improve the initiative of learning. In this way, the whole learning process is no longer a tedious process, which enables students to study independently and stimulate their interest in learning.

\section{TEACHING DESIGN OF BLENDED LEARNING IN UNDERGRADUATE COURSES.}

In recent years, a new teaching method MOOC has gradually become popular in various colleges and universities. As a new teaching mode, MOOC has provided a new online learning mode. On the one hand, because of course open, longed for class platform is generally based on the Internet instead of a local area network (LAN), open to all the public, not only limited to a certain school or agency official learner, need not pay can also study. Under this premise, everyone can provide learning resources and topics for MOOCs, and can participate in various learning and exchange activities, which can provide a lot of high-quality teaching resources for teachers and students. On the other hand, in the intermediate stage of each class, we will combine the corresponding improvement exercises to provide students with the necessary practice. However, it is separated from the supervision of teachers in traditional face-to-face classroom teaching, which leads to higher dropout rate and lower completion rate. Therefore, it is necessary to 
combine offline learning with online learning and different theoretical teaching modes. Combined with the quality teaching resources of MOOC teaching, a new blended learning teaching is carried out, which not only exerts the advantage of MOOCs, but also avoids its own disadvantages.

\section{A. Design the Online Teaching Resources Required in the Process of Blended Learning}

Colleges and universities should take advantage of the existing college website resources, open various professional courses website areas, and gradually improve the construction of online basic resources of specialized courses. Use for class resources, the introduction of open courses abroad, introducing international excellent cases, foreign related video courses, the course content can face the world, can reflect the latest achievements within the scope of this discipline. At the same time, we will open a work display area for students, jointly build learning resources with students, and jointly improve the online learning resources area of each specialized course.

\section{B. Teaching Design of Mixed Learning}

\section{1) The teaching design}

To determine the teaching objective by teachers and organize the teaching content, upload related teaching materials to have build specialized courses online resources area, at the same time, design the teaching strategies, including classroom teaching and network teaching environment, Make full use of the existing multimedia resources to enable students to study and explore on the Internet. Supervise and coach students in class. After class, the students can put forward their own confusion and problems, and answer questions online.

\section{2) Classroom teaching.}

In the face-to-face teaching process, teachers should give full play to the leading role, create the background of problems through multimedia materials and PPT, and encourage students to explore and ask questions. At the same time to carry out the teaching of basic theory, introduces the theory of class specialized courses teach students, and proposes the case in the form of broadcast video information, combined with the specific case analysis problem, organize students to discuss in small groups. Encourage students to speak enthusiastically in groups.

\section{3) Instruction after class.}

Time after class, the teacher should make full use of online learning resources, developing students' online learning activities, little homework on a regular basis and to carry out online testing activities, provide necessary resources of student's study, strengthen the communication between teachers and students, targeted guidance to students.

\section{4) Course assessment.}

Change the traditional way of assessment, increase the proportion of normal grades, and pay attention to the assessment of students in the study and practice activities. Using online test sites similar to the approval network, regular online testing is carried out to record the results.

\section{V.THE REFLECTION ON THE TEACHING PRACTICE OF BLENDED LEARNING IN COLLEGES AND UNIVERSITIES.}

Blended learning is the integrity of complex learning teaching strategies, namely the combination of different learning theories, different education technology and means, different teaching methods to organize the teaching of learning strategies. This teaching mode can achieve the optimal teaching effect in a limited time, improve students' learning efficiency, and cultivate students' advanced thinking ability and practical combat ability. Therefore, in the process of teaching practice group to build stable teaching team, from the perspective of complex learning theory on integrity of teaching design, trains the student to form the good habit of autonomous learning become to promote the basic requirement of blended learning teaching mode.

\section{A. Blended Learning Should Form a Stable Teaching Team.}

Currently, blended learning is under the background of information age high-quality teaching resources, teaching means, teaching methods of integration, has the characteristics of openness, sharing and generative, through form stable teaching team can give full play to the information resources sharing platform, complementary technology and diversified teaching demands. To advance, head of the course teaching reform, form the experienced teachers to drive the young teachers, with young teachers of modern information technology to promote curriculum platform construction, achieve coordinated division of labor cooperation, sharing common maintenance course teaching resources platform, and achieve the growth of high quality teaching and teacher multiple goals.

\section{B. Mixed Learning Should Build a Holistic Teaching Design Scheme.}

Blended learning is based on the theory of complex learning the integrity of the teaching design and teaching thinking paradigm, which emphasizes the teaching process of "learning" and "teach" design, also emphasizes the teaching organization and evaluation of process control and process assessment and design, pay attention to students' learning process evaluation. Blended learning teaching effective design including the design of online teaching resources, learning task clear requirements, to facilitate students to master the knowledge points, on time to complete the homework problems and online self-test self-study links such as; Also facilitate teachers finish online tutoring and feedback the situation of students' learning, completes the face-to-face teaching supplement of online learning and improve, highlight the emphasis, difficulty and form online complement each other, the students basic knowledge with the knowledge of cohesion, solve the "learning" and "teaching" and "learning" and "learning", "learning" and "evaluation" of teaching learning plan as a whole.

\section{Blended Learning must Require Students to Develop a Good Habit of Autonomous Learning.}


Blended learning give students learning time and the selection of learning content, learning space, meet the requirement of students' personalized learning environment, but also the students really effective learning, whether high quality complete related tasks, depending on the teaching strategies on students' learning autonomy.

\section{SUMMARY}

Although in recent years, online learning began to pop up in the teaching practice of the universities and colleges of undergraduate course, more and more teachers begin to pay attention to the campus of the existing network resources use, especially for teaching resources with high quality. But we should still be aware that traditional classroom teaching must be combined with the current popular online learning approach. To give full play to the role of teachers as supervisors and mobilize students' independent learning initiative can effectively improve the teaching quality of undergraduate colleges.

\section{REFERENCE}

[1] SinghH,Reed C. A white paper:Achieving success with blended learning[OL].

http://www.centra.com/download/whitepapers/blended learning.pdf

[2] Driscoll M. Blended Learning: Let's get beyond the hype[EB/OL] http://www.e-learning mag.com(2002,March 1).

[3] Josh Bersin. Blended learning: what works? [DB/OL] www.bersin.com.(2003)

[4] Carman JM. Blended learning design: Five key ingredients[J]. Retrieved August, 2002,18:2009.

[5] Kerres M, Witt CD.A didactical framework for the design of blended learning arrangements[J]. Journal of Educational Media, 2003, 28(2-3): 101-113.

[6] López-Pérez MV, Pérez-López MC, Rodríguez-Ariza L. Blended learning in higher education: Students'perceptions and their relation to outcomes[J]. Computers \& Education, 2011, 56(3): 818-826.

[7] Lim DH, Morris ML. Learner and instructional factors influencing learning outcomes within a blended learning environment[J]. Educational Technology \& Society, 2009, 12(4): 282-293. 